\title{
RHIZOSPHERE MICROBIOME: AN EMERGING FRONTIER IN CAUSING AND CURING INFECTIOUS DISEASES
}

\author{
RENU CHAUDHARY ${ }^{1}$, MEENAKSHI BALHARA ${ }^{1}$, MRRIDULA DANGI ${ }^{1}$, MEHAK DANGI ${ }^{2}$, ANIL K CHHILLAR ${ }^{1 *}$ \\ ${ }^{1}$ Centre for Biotechnology, Maharshi Dayanand University, Rohtak, Haryana, India. ${ }^{2}$ Centre for Bioinformatics, Maharshi Dayanand \\ University, Rohtak, Haryana, India. Email: anil.chhillar@gmail.com
}

Received: 15 February 2018, Revised and Accepted: 16 March 2018

\begin{abstract}
Prevalence of pathogenic microorganisms in the rhizosphere causing infectious diseases in plants and humans has increased considerably due to a high content of nutrients. Such pathogenic infections are of huge concern in agriculture, health care, and medical arenas. Rhizosphere microbiome is a "microbial hotspot," not only for pathogenic microorganism but also for unlimited beneficial microorganisms. Therefore, this microbiome has immense potential in the shaping of earth from natural vegetation to the intense agricultural production to human health. Rhizosphere microorganism from unexplored habitats is a promising approach to overcome the escalating threat of such pathogenic infections. Hence, efforts are being made to isolate more and more rhizobacteria that are beneficial for better plant productivity and for treating human diseases. Thus, present review highlights and discusses the available literature on beneficial/pathogenic microorganisms belonging to rhizosphere and their impact on plants and human diseases. Furthermore, it sheds light on how this novel knowledge helps in deriving maximum benefits out of this naturally occurring population for the betterment of plant and human health.
\end{abstract}

Keywords: Beneficial microbes, Health, Pathogenic, Rhizosphere, Rhizobacteria.

(C) 2018 The Authors. Published by Innovare Academic Sciences Pvt Ltd. This is an open access article under the CC BY license (http://creativecommons. org/licenses/by/4. 0/) DOI: http://dx.doi.org/10.22159/ajpcr.2018.v11i6.25299

\section{INTRODUCTION}

Recent reviews of the scientific literature have highlighted that the proliferation of rhizospheric pathogenic microorganisms affecting both plants and humans (particularly in immune compromised individuals) has increased significantly during the past few decades [1-3]. Infections by these microorganisms are of grave concern when it comes to areas such as agriculture, medicine, and health care. The number of therapeutic options for the treatment of these infections is quite limited. In fact, presently available drugs are not optimal due to their low efficacy, toxicity and the emergence of drug resistance in pathogenic microbes [4]. Hence, it has become imperative to look for novel antimicrobials from the unexplored habitats that can help in the future to mitigate the increasing threat of drug-resistant strains related to human and plant pathogens.

The considerable amount of research is going on worldwide in search of antimicrobial agents which could counter the threat of infectious diseases. Soils have been continuously screened in the past for potent microorganisms, and nowadays major focus has shifted to rhizosphere as it represents one of the richest habitats of microbes. Recent metagenomics and meta-transcriptomics approaches have also been explored on more rhizosphere microbiota [4-6] as shown in (Table 1). Bacteria, algae, fungi, and protozoa are some of the microorganisms which are associated with colonization in plant roots. These microorganisms have beneficial, harmful, and/or neutral effects on the plant growth and development $[7,8]$ as shown in Fig. 1. Applications of these microbial populations enhance plant growth and provide defense against pathogenic microorganisms, facilitating the nutrient acquisition and thus help plants withstand stressful conditions [9-12]. Another type of microorganisms present in the rhizosphere is phytopathogens and opportunistic pathogens which have a severe impact on plant and human health. Therefore, understanding the basic mechanism and characteristics of rhizosphere microbiome is a major task to maintain the plant productivity and to defend human wellbeing. The present review highlights and discusses the present knowledge of beneficial and pathogenic rhizospheric microorganisms and their impact on human and plant diseases. Moreover, we have tried to shed light on how this knowledge could be helpful in deriving maximum benefits out of this naturally occurring population.

\section{IMPACT OF RHIZOSPHERE MICROBIOME ON PLANTS}

The synthesis and efficiency of the natural plant communities (i.e., biomass) are directly and/or indirectly influenced by rhizosphere microbiome [28]. Pathogens (human as well as a plant) also form part of the plant associated microbiomes besides the majority of beneficial and neutral inhabitants. These pathogenic microbes are the subject of huge concern, particularly for plant growth and the environment [3]. Examining these microorganisms by unraveling their likely association with plants opened new doors for fascinating study related to rhizosphere research. Therefore, here, we will discuss the role of pathogenic microbes in the rhizosphere and how beneficial microbes from same or different plant rhizosphere can be useful in managing these problems.

\section{Pathogenic interactions}

One of the major obstacles to the production of adequate supplies of food, feed, fiber, and fuel is the damages caused by phytopathogens. Most studies till date on plant pathogens revealed that rhizosphere can be considered as the infectious courtyard where soil-borne pathogens, including bacteria, fungi, oomycetes, and nematodes entrenched a parasitic association with the plant. Pathogens emit particular classes of effectors into the apoplast or inside the plant cell to incite infections in the root tissue [29,30]. From, the past two decades the effect of pathogenic fungi on plant health has expanded significantly. There are two major groups of plant pathogens, i.e., fungi and nematodes [31]. The fungal and oomycetes pathogens, i.e., Aspergillus, Fusarium, Phytophthora, Collectrichum, Pythium, Verticillium, Rhizopus, and Rhizoctonia present in rhizosphere crops, and few bacterial genera (i.e., Pectobacterium carotovorum, Dickeya dadantii, Ralstonia solanacearum, Pectobacterium atrosepticum, and Dickeya solani) are responsible for significant loss of grain worldwide and result in economic repercussions [31] 
Table 1: Bacterial and archaeal taxa recognized in the rhizosphere

\begin{tabular}{|c|c|c|c|}
\hline Host & Methodology & Rhizosphere microbiome composition & References \\
\hline Oat microcosms & 16S rRNA gene microarray & $\begin{array}{l}\text { Identification of } 1917 \text { taxa by Firmicutes and } \\
\text { Proteobacteria community dominance. Detection } \\
\text { of less expected rhizosphere-competent } \\
\text { phyla (Actinobacteria, Verrucomicrobia, and } \\
\text { Nitrospira). }\end{array}$ & [13] \\
\hline D. antarctica and C. quitensis & 16S rRNA gene pyrosequencing & $\begin{array}{l}\text { Firmicutes and seldom detected groups Acidobacteria } \\
\text { Arcobacter (phylum Proteobacteria), Faecalibacterium } \\
\text { (phylum Firmicutes), and Bifidobacterium (phylum } \\
\text { Actinobacteria) were found to be most predominant } \\
\text { genera }\end{array}$ & {$[14]$} \\
\hline Oak (forest soil) & 16S rRNA gene pyrosequencing & $\begin{array}{l}\text { Predicted predominant phyla were found to } \\
\text { be Actinobacteria (11\%), Acidobacteria ( } 24 \%) \text {, } \\
\text { Proteobacteria (38\%), and including a high proportion } \\
\text { of unclassified bacteria ( } 20 \%) \text {. Identification of } 5619 \\
\text { OTUs in one of the bacterial community. }\end{array}$ & {$[15]$} \\
\hline Potato field soil & 16S rRNA gene microarray & $\begin{array}{l}\text { Detection of } 2432 \text { OTUs with the highest number } \\
\text { belonging to Proteobacteria ( } 46 \% \text { ), and least } \\
\text { to Acidobacteria ( } 3 \%) \text {, Micromonosporaceae } \\
\text { Streptomycetaceae, and Pseudomonadaceae bacterial } \\
\text { families was found to exhibit the strongest response at } \\
\text { the potato cultivar level. }\end{array}$ & {$[17]$} \\
\hline $\begin{array}{l}\text { R. mangle and } L . \\
\text { racemosa (mangrove) }\end{array}$ & $\begin{array}{l}\text { Archaeal } 16 \mathrm{~S} \text { rRNA gene } \\
\text { pyrosequencing }\end{array}$ & $\begin{array}{l}\text { Identification of } 300 \text { archaeal OTUs along-with } \\
\text { detection of Halobacteria, Methanobacteria, } \\
\text { Methanomicrobia, and Thermoprotei classes. }\end{array}$ & [18] \\
\hline Potato (field soil) & Pyrosequencing & $\begin{array}{l}\text { Identification of } 55121 \text { OTUs with Actinobacteria and } \\
\text { Alphaproteobacteria as most abundant groups. }\end{array}$ & [19] \\
\hline R. mangle (mangrove) & 16S rRNA gene pyrosequencing & Most abundant phylum detected was Proteobacteria. & {$[20]$} \\
\hline A. thaliana (cologne and golm soils) & 16S rRNA gene pyrosequencing & $\begin{array}{l}\text { Estimation of } 1000 \text { OTUs was identified in the root } \\
\text { and rhizosphere compartments with the dominance } \\
\text { of Acidobacteria, Proteobacteria, Planctomycetes, and } \\
\text { Actinobacteria. Most prevailing phyla includes } \\
\text { Proteobacteria, Actinobacteria, and Bacteroidetes. }\end{array}$ & [22] \\
\hline $\begin{array}{l}\text { A. thaliana (Mason farm and clayton } \\
\text { soil) }\end{array}$ & 16S rRNA gene pyrosequencing & $\begin{array}{l}\text { Identification of } 18783 \text { bacterial OTUs with the } \\
\text { dominance of Bacteroidetes, Actinobacteria, and } \\
\text { Proteobacteria, Acidobacteria. }\end{array}$ & {$[23]$} \\
\hline S. tuberosum in high andes & 16S rRNA gene pyrosequencing & $\begin{array}{l}\text { Identification of } 479 \text { OTUs belonged to seven phyla } \\
\text { with the dominance of Proteobacteria, Firmicutes, and } \\
\text { Actinobacteria }\end{array}$ & {$[24]$} \\
\hline S. saponaria L. & 16S rRNA gene pyrosequencing & $\begin{array}{l}\text { Twenty-six phyla were identified from } 5089 \\
\text { sequences of } 16 \text { S rRNA gene. Most predominance was } \\
\text { Actinobacteria ( } 33.54 \%) \text {, Acidobacteria }(22.62 \%) \text {, and } \\
\text { Proteobacteria }(24.72 \%) \text {. }\end{array}$ & {$[25]$} \\
\hline L. japonicas & 16S rRNA genes & Two nodule-enriched OTUs among a total of 1834 & [26] \\
\hline S. oleracea L., cv. Racoon & 16S rRNA genes & $\begin{array}{l}\text { OTUs. Mesorhizobium members representing the most } \\
\text { abundant taxa } \\
\text { Three phyla Proteobacteria, Cyanobacteria, and } \\
\text { Bacteroidetes were dominant and accounted for } 77.1 \% \\
\text { of taxa in the rhizosphere, while Proteobacteria, } \\
\text { Bacteroidetes, and Actinobacteria accounted for } 55.1 \% \\
\text { of taxa as detected in soil. }\end{array}$ & {$[27]$} \\
\hline
\end{tabular}

D. antarctica: Deschampsia antarctica, C. quitensis: Colobanthus quitensis, R. mangle: Rhizophora mangle, L. racemosa: Laguncularia racemosa, M. carnea: Mammillaria carnea, A. thaliana: Arabidopsis thaliana, S. tuberosum: Solanum tuberosum, S. saponaria L., Sapindus saponaria L., L. japonicas: Lotus japonicas, S. oleracea L: Spinacia oleracea L, OTUs: Operational taxonomic units

Beneficial effect of rhizosphere microbial community on plant Plant rhizosphere not only comes across as one of the natural reservoirs for disease-causing microorganisms but also they are also the habitat for unlimited beneficial microorganisms with the larger biotechnological applications to enhance plant growth and productivity. However, the main challenge in promoting their possibilities lies in understanding 
the natural variations and possible differences that exist between pathogens and beneficial microbes.

Rhizosphere microorganisms have been widely considered for their beneficial effects on plant development and wellbeing and are observed to be required in biofertilization, incitement of root development, rhizoremediation, control of abiotic/biotic stresses, and diseases. These mechanisms have been recognized to be carried out by rhizobacteria belong to Proteobacteria and Firmicutes (Pseudomonas and Bacillus), fungi from Deuteromycetes class (Gliocladium and Trichoderma), and Sebacinales order (Piriformospora) [32].

Rhizosphere microbiome can significantly affect plant productivity by controlling the nutrient status of the plants. Nitrogen fixating bacteria, such as Mycorrhiza and Rhizobium, present in the rhizosphere of various crop plants help in the uptake of phosphorus and nitrogen, respectively [33-35]. Rhizobium and Bradyrhizobium found in the root nodules of leguminous plants converts atmospheric nitrogen into useful key compounds that can be utilized by the plants and humans [36]. Inoculation of plant growth promoting rhizobacteria (PGPR), i.e., Bacillus pumilus $\mathrm{S} 1 \mathrm{r} 1$ has been reported to be an alternative method for naturally fixating atmospheric nitrogen in delaying the nitrogen remobilization in maize plants to get a higher yield with less utilization of nitrogen fertilizers [37]. Some other PGPR were also found to release organic phosphate or solubilize the insoluble phosphate, thereby enabling the plant growth and productivity [38]. Pseudomonas, Penicillium, Bacillus, Micrococcus, Sclerotium, Flavobacterium, Aspergillus, and Fusarium have been testified to be highly involved in the solubilization process $[39,40]$. Various Siderophores producing rhizobacteria such as Bacillus subtilis (strain GB03), and Paenibacillus polymyxa (BFKC01) have been found to activate iron acquisition machinery to increase metal ion assimilation in Arabidopsis. A study conducted on inoculation of shoot propagated cassava with B.subtilis (strain GB03) has exhibited higher iron accumulation following 140 days of plant development as detected by X-beam microanalysis and total foliar iron analysis. Whereas BFKC01inoculated plants demonstrated that BFKC01 transcriptionally actuates the Fe-insufficiency instigated translation Factor 1, in this manner up directing the outflow of IRT1 and FRO2. Thusly, BFKC01-inoculated plants have more endogenous $\mathrm{Fe}$ and expanded photosynthetic limit under basic conditions when contrasted with control plants. It ultimately results in growth promotion and increased photosynthetic efficiency in Arabidopsis plants [41,42]. It has also been elucidated that the inoculation of arbuscular mycorrhizal fungi with plant enhances plant growth under high salt concentration [43]. A study conducted by a team of a biologist, using rhizosphere technology elucidates that Pseudomonas aeruginosa, Pseudomonas fluorescens, Mycobacterium spp., Haemophilus spp., Rhodococcus spp., and Paenibacillus spp. are some of the most commonly studied polyaromatic hydrocarbons degrading bacteria in the rhizosphere [44].

Apart from the above mentioned beneficial effects of rhizosphere microbiome they are also seem to be frontline defense toward phytopathogens. One of the most widely recognized biocontrol mechanisms driven by PGPR includes antibiosis, (inhibition of the pathogenic microbial growth by producing antibiotics), biosurfactants, and volatile organic compounds. Production of metabolites, i.e., antibiotics by rhizospheric bacteria, is often implicated as an important bio-control mechanism because it is relatively simplest and most effective mechanism to study. A work carried out by Sahoo et al., on PGPR (Bacillus amyloliquefaciens 937b and B. pumilus SE-34) showed protection against tomato mottle virus (TMV) [45]. Another study carried out on Streptomycetes cacaoi strain M-20 isolated from Avicennia marina rhizosphere has also shown antifungal activity against phytopathogen Fusarium oxysporum, which was reported to be responsible for the significant reduction in legume production [46]. Some studies had observed that the mycorrhizae bacteria provide resistance against fungal pathogens by inhibiting the growth of many root pathogens such as Rhizoctonia solani, Pythium spp., F. oxysporum, and Heterobasidion annosum (Fig. 2) [43].

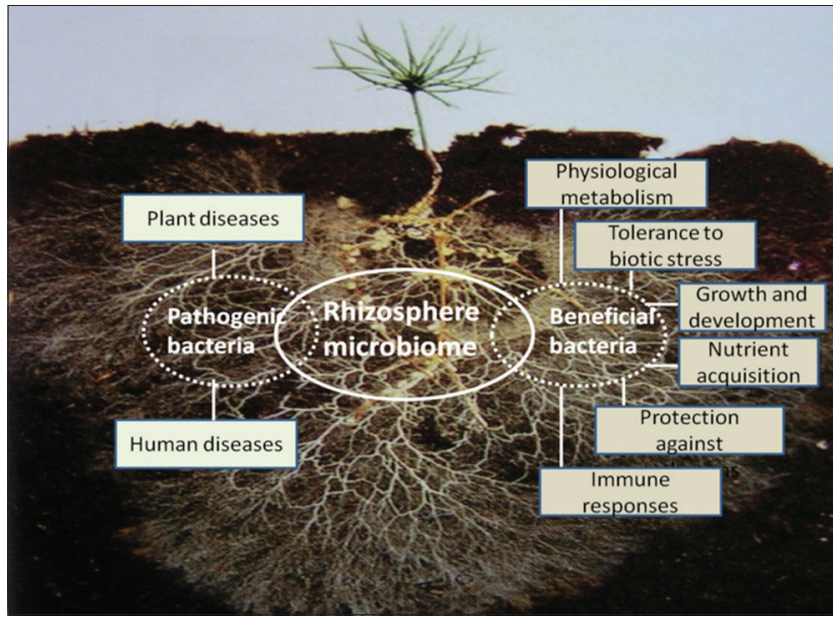

Fig. 1: Graphical representation of the functions and outcome of rhizosphere microorganism

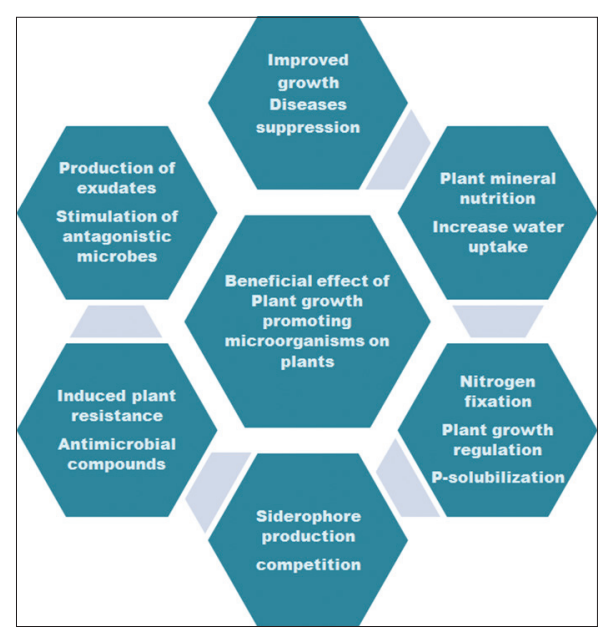

Fig. 2: Potential modes of action of plant growth promoting bacteria

Impact of rhizosphere microbiome on human health

Rhizosphere microbiomes serve not only as sources of plant pathogens and beneficial microbiomes but they have also been found to function as a foundation as well as treatment of opportunistic human pathogens as discussed here.

\section{Rhizosphere, a reservoir of opportunistic human pathogens}

Opportunistic human pathogens normally does not harm its host, but can cause diseases in the individuals with weakened immune system, particularly those undergoing blood and bone marrow transplantation, major surgery (especially gastrointestinal surgery); patients with AIDS, solid-organ transplantation, neoplastic disease, premature infants, and patients receiving immunosuppressive therapy $[47,48]$. Infections by these pathogens lead to serious or even deadly complications in patients with compromised immune systems. In the past two decades, the effect of opportunistic infection on human wellbeing has expanded significantly. In spite of this fact, little is known about the nature and the pathogenesis of these emergent pathogens. Some of these opportunists originate in the rhizosphere, which is the zone around plant roots $[1,49]$. A number of studies on rhizosphere microbiome highlighted the prevalence of opportunistic human pathogens in wild and cultivated plant species (such as P. aeruginosa, Burkholderia cepacia, or Stenotrophomonas maltophilia) [49]. However, there is relatively less information available regarding the virulence, adaptation, and survival of other bacterial species that were identified in rhizosphere and have been 
associated with skin, urinary tract infections, and wound (e.g., Proteus vulgaris and Bacillus cereus) [49,50]. Several factors responsible for the incidence of opportunistic human pathogens in the rhizosphere include higher nutrient content, access to water for dispersal and prevention from dehydration, protection from ultraviolet radiation [49,51]. A study carried out by a scientist suggested that the roots release a chemical stimulus that activates chemotaxis in S. enterica which in turn switches on the genes responsible for adherence to plant surfaces. Numerous other genes and characters have also been identified to be responsible for the attachment of the opportunistic pathogens to plantsurfaces, together with adhesins, capsule production and fimbriae [52]. Polyphasic approaches, conducted on genotype PaBP35, comprising recN sequence analysis, BOX-polymerase chain reaction, comparative genome hybridization analysis and multilocus sequence typing, discovered the uniqueness of $P$. aeruginosa strains on behalf of the clinical habitats. However, further analysis revealed that certain traits of PaBP35, such as growth at $25-41^{\circ} \mathrm{C}$, resistance to antibiotics, and production of phenazines, and rhamnolipids besides exhibiting cytotoxicity on mammalian A549 cells, were similar to other Paeruginosa strains [53]. Recently, more studies on polyphasic approaches on rhizosphere microbiome revealed that Rhizobium pusense is the main human pathogen within Agrobacterium (Rhizobium) spp. [54]. Some other phytopathogenic fungus, such as Fusarium solani and Colletotrichum, are also considered as human pathogens. Recent studies have also highlighted as to how bacteria (Vibrio parahaemolyticus) developed a mechanism to quench iron from the human host using siderophores and xenosiderophores, proteases, and iron-protein receptors [55]. Siderophore (yersiniabactin) delivered by uropathogenic Escherichia coli bind with copper particles during human diseases. Thus, protect E. coli from copper lethality and redox-based phagocyte which makes it distinct from other E. coli siderophores [56].

\section{Role of rhizosphere microbiome in fighting opportunistic infections}

Plant-associated microbiome leads to significant outbreaks of contagious diseases in initiating transfer of potential pathogens [54], they also act as a source of beneficial bacteria that inhibit survival of human pathogens and therefore can positively influence human health [57]. Studies on Burkholderia genus (naturally present in the rhizosphere of crop plants) revealed that Burkholderia contaminans (MS14) strain produces an antifungal compound, occidiofungin, which triggers considerable antifungal activities against a wide range of invasive fungal pathogens (plant and animal) [58]. Similar studies were carried out on carried on sagebrush rhizospheric soil isolates (phenolresistant and humic acid, vitamin) had revealed the broad-spectrum antifungal, antibiotic activity against Pythium ultimum and Candida albicans strains. Phylogenetic analysis of these isolates showed a close resemblance to Streptomyces violaceusniger clade [59]. The metabolites of Streptomycetes cellulosae VJDS-1 isolated from mangrove soil of Nizampatnam, Guntur, (Andhra Pradesh), India, had also reported the antimicrobial against Gram-positive (Staphylococcus aureus and Bacillus megaterium), Gram-negative bacteria (Xanthomonas campestris and P. aeruginosa, E. coli), and fungi (Aspergillus niger, C. albicans, F. solani, and F. oxysporum) [60]. Antibiotics, including amphisin, 2,4-diacetylphloroglucinol, pyoluteorin, pyrrolnitrin, tensin, tropolone, kanosamine, Oligomycin A, xanthobaccin, and Zwittermicin A identified in antagonistic Gram-negative bacteria, such as Pseudomonads, Bacillus, Streptomyces, and Stenotrophomonas, are multidrug-resistant against human pathogenic bacteria [61]. Biosurfactants, produced mostly by rhizobacterial population, were also found to have antimicrobial activity against human pathogenic Gram-positive (S. aureus) and Gram-negative (P. vulgaris) bacteria [62]. Recently, targeting iron acquisition in the cystic fibrosis lung has been found to be a novel therapeutic strategy for cystic fibrosis and aspergillosis [63]. Hence, an antibiotic produced by rhizosphere microbiome is a "hotspot" for potential therapeutic developments, yet, in-depth knowledge is required on these antibiotics.

\section{CONCLUSION}

The significance of the rhizosphere microbiome in the functioning of plant biological communities has been broadly recognized. Traditional ways to deal with disentangle these functions are constrained in their ability and for most of rhizosphere microorganism, no information exists. There are still certain aspects which need further investigations to derive maximum benefits such as improved plant growth and human health out of these naturally occurring populations, particularly under distress and unfavorable ecological conditions. The majority of the work on this topic has focused on the functional roles of the single microbial population with plants, mostly because of the methodological restriction associated with nonculturable microbial populations. A combination of traditional and next-generation sequencing techniques to identify and characterize the organism/community ecology and physiology will help in understanding the microbial life and their role in the rhizosphere, thereby, opening new opportunities for novel discoveries. Hence, we conclude that comprehensive knowledge of rhizosphere microbiome can be useful in many areas including the discovery of novel drugs, inhibiting the proliferation of human pathogens in plant environments and protection from current and future emerging diseases.

\section{ACKNOWLEDGMENT}

The authors would like to thank M.D. University, Rohtak, India, for providing University Research scholarship.

\section{CONFLICTS OF INTEREST}

The authors confirm that this article content has no conflicts of interest (none to declare).

\section{REFERENCES}

1. Teplitski M, Warriner K, Bartz J, Schneider KR. Untangling metabolic and communication networks: Interactions of enterics with phytobacteria and their implications in produce safety. Trends Microbiol 2011;19:121-7.

2. Kaestli M, Schmid M, Mayo M, Rothballer M, Harrington G, Richardson L, et al. Out of the ground: Aerial and exotic habitats of the melioidosis bacterium Burkholderia pseudomallei in grasses in australia. Environ Microbiol 2012;14:2058-70.

3. Mendes R, Garbeva P, Raaijmakers JM. The rhizosphere microbiome: Significance of plant beneficial, plant pathogenic, and human pathogenic microorganisms. FEMS Microbiol Rev 2013;37:634-63.

4. Mahajan GB, Balachandran L. Sources of antibiotics: Hot springs. Biochem Pharmacol 2017;134:35-41.

5. Pérez-Montaño F, Alías-Villegas C, Bellogín RA, del Cerro P, Espuny MR, Jiménez-Guerrero I, et al. Plant growth promotion in cereal and leguminous agricultural important plants: From microorganism capacities to crop production. Microbiol Res 2014;169:325-36.

6. Herrmann J, Lukežič T, Kling A, Baumann S, Hüttel S, Petković H, et al. Strategies for the discovery and development of new antibiotics from natural products: Three case studies. Curr Top Microbiol Immunol 2016;398:339-63.

7. Ahmad I, Ahmad F, Pichtel J. Microbes and Microbial Technology: Agricultural and Environmental Applications. Netherlands: Springer Science+Business Media; 2011. p. 1-516.

8. Lau JA, Lennon JT. Evolutionary ecology of plant-microbe interactions: Soil microbial structure alters selection on plant traits. New Phytol 2011;192:215-24.

9. Bhattacharyya PN, Jha DK. Plant growth-promoting rhizobacteria (PGPR): Emergence in agriculture. World $\mathrm{J}$ Microbiol Biotechnol 2012;28:1327-50.

10. Ma Y, Rajkumar M, Zhang C, Freitas H. Beneficial role of bacterial endophytes in heavy metal phytoremediation. J Environ Manage 2016;174:14-25.

11. Saharan BS, Nehra V. Plant growth promoting rhizobacteria: A critical review. Life Sci Med Res 2011;2011:1-30.

12. Berendsen RL, Pieterse CM, Bakker PA. The rhizosphere microbiome and plant health. Trends Plant Sci 2012;17:478-486.

13. DeAngelis KM, Brodie EL, DeSantis TZ, Andersen GL, Lindow SE, Firestone MK, et al. Selective progressive response of soil microbial community to wild oat roots. ISME J 2009;3:168-78.

14. Teixeira LC, Peixoto RS, Cury JC, Sul WJ, Pellizari VH, Tiedje J, et al. Bacterial diversity in rhizosphere soil from antarctic vascular plants of admiralty bay, maritime antarctica. ISME J 2010;4:989-1001.

15. Uroz S, Buée M, Murat C, Frey-Klett P, Martin F. Pyrosequencing reveals a contrasted bacterial diversity between oak rhizosphere and surrounding soil. Environ Microbiol Rep 2010;2:281-8. 
16. Mendes R, Kruijt M, de Bruijn I, Dekkers E, van der Voort M, Schneider JH, et al. Deciphering the rhizosphere microbiome for disease-suppressive bacteria. Science 2011;332:1097-100

17. Weinert N, Piceno Y, Ding GC, Meincke R, Heuer H, Berg G, et al. PhyloChip hybridization uncovered an enormous bacterial diversity in the rhizosphere of different potato cultivars: Many common and few cultivar-dependent taxa. FEMS Microbiol Ecol 2011;75:497-506.

18. Pires AC, Cleary DF, Almeida A, Cunha Â, Dealtry S, Mendonça-Hagler LC, et al. Denaturing gradient gel electrophoresis and barcoded pyrosequencing reveal unprecedented archaeal diversity in mangrove sediment and rhizosphere samples. Appl Environ Microbiol 2012;78:5520-8.

19. Inceoğlu Ö, Al-Soud WA, Salles JF, Semenov AV, van Elsas JD. Comparative analysis of bacterial communities in a potato field as determined by pyrosequencing. PLoS One 2011;6:e23321.

20. Gomes NC, Cleary DF, Pinto FN, Egas C, Almeida A, Cunha A, et al. Taking root: Enduring effect of rhizosphere bacterial colonization in mangroves. PLoS One 2010;5:e14065.

21. Torres-Cortés G, Millán V, Fernández-González AJ, AguirreGarrido JF, Ramírez-Saad HC, Fernández-López M, et al. Bacterial community in the rhizosphere of the cactus species Mammillaria carnea during dry and rainy seasons assessed by deep sequencing. Plant Soil 2012;357:275-288.

22. Bulgarelli D, Rott M, Schlaeppi K, van Themaat E, Ahmadinejad N, Assenza F, et al. Revealing structure and assembly cues for arabidopsis root-inhabiting bacterial microbiota. Nature 2012;488:91-5.

23. Lundberg DS, Lebeis SL, Paredes SH, Yourstone S, Gehring J, Malfatti S, et al. Defining the core Arabidopsis thaliana root microbiome. Nature 2012;488:86-90.

24. Pfeiffer S, Mitter B, Oswald A, Schloter-Hai B, Schloter M, Declerck S, et al. Rhizosphere microbiomes of potato cultivated in the high andes show stable and dynamic core microbiomes with different responses to plant development. FEMS Microbiol Ecol 2017; 93: pii: fiw242.

25. Garcia A, Polonio JC, Polli AD, Santos CM, Rhoden SA, Quecine MC, et al. Rhizosphere bacteriome of the medicinal plant sapindus saponaria L. Revealed by pyrosequencing. Genet Mol Res 2016;3:15(4)

26. Zgadzaj R, Garrido-Oter R, Jensen DB, Koprivova A, Schulze-Lefert P, Radutoiu S, et al. Root nodule symbiosis in Lotus japonicus drives the establishment of distinctive rhizosphere, root, and nodule bacterial communities. Proc Natl Acad Sci U S A 2016;113:E7996-E8005.

27. Ibekwe AM, Ors S, Ferreira JF, Liu X, Suarez DL. Seasonal induced changes in spinach rhizosphere microbial community structure with varying salinity and drought. Sci Total Environ 2017;1:1485-95.

28. Schnitzer SA, Klironomos JN, Hillerislambers J, Kinkel LL, Reich PB, Xiao K, et al. Soil microbes drive the classic plant diversity-productivity pattern. Ecology 2011;92:296-303.

29. Chapelle E, Mendes R, Bakker PA, Raaijmakers JM. Fungal invasion of the rhizosphere microbiome. ISME J 2016;10:265-8.

30. Dou D, Zhou JM. Phytopathogen effectors subverting host immunity: Different foes, similar battleground. Cell Host Microbe 2012;12:484-95.

31. Mansfield J, Genin S, Magori S, Citovsky V, Sriariyanum M, Ronald P, et al. Top 10 plant pathogenic bacteria in molecular plant pathology. Mol Plant Pathol 2012;13:614-29.

32. Qiang X, Weiss M, Kogel KH, Schäfer P. Piriformospora indica-a mutualistic basidiomycete with an exceptionally large plant host range. Mol Plant Pathol 2012;13:508-18.

33. Doornbos RF, Van Loon LC, Bakker PA. Impact of root exudates and plant defense signaling on bacterial communities in the rhizosphere. A review. Agron Sustain Dev 2012;32:227-43.

34. Ferrara FI, Oliveira ZM, Gonzales HH, Floh EI, Barbosa HR. Endophytic and rhizospheric enterobacteria isolated from sugar cane have different potentials for producing plant growth-promoting substances. Plant Soil 2012;353:409-17.

35. Kavamura VN, Santos SN, Silva JL, Parma MM, Avila LA, Visconti A, et al. Screening of brazilian cacti rhizobacteria for plant growth promotion under drought. Microbiol Res 2013;168:183-91.

36. Sharma P, Sardana V, Kandola SS. Response of groundnut (Arachis hypogaea L.) to rhizobium inoculation. Libyan Agric Res Center J Intern 2011;2:101-4.

37. Kuan KB, Othman R, Abdul Rahim K, Shamsuddin ZH. Plant growth-promoting rhizobacteria inoculation to enhance vegetative growth, nitrogen fixation and nitrogen remobilisation of maize under greenhouse conditions. PLoS One 2016;11:e0152478

38. Oteino N, Lally RD, Kiwanuka S, Lloyd A, Ryan D, Germaine KJ, et al. Plant growth promotion induced by phosphate solubilizing endophytic Pseudomonas isolates. Front Microbiol 2015;6:745.

39. Bakhshandeh E, Rahimian H, Pirdashti H, Nematzadeh GA. Evaluation of phosphate-solubilizing bacteria on the growth and grain yield of rice (Oryza sativa L.) cropped in northern iran. J Appl Microbiol $2015 ; 119: 1371-82$

40. Pindi PK, Satyanarayana SD. Liquid microbial consortium-a potential tool for sustainable soil health. J Biofertil Biopestici 2012;3:124.

41. Freitas MA, Medeiros FH, Carvalho SP, Guilherme LR, Teixeira WD, Zhang $\mathrm{H}$, et al. Augmenting iron accumulation in cassava by the beneficial soil bacterium Bacillus subtilis (GBO3). Front Plant Sci 2015;6:596.

42. Zhou C, Guo J, Zhu L, Xiao X, Xie Y, Zhu J, et al. Paenibacillus polymyxa $\mathrm{BFKC01}$ enhances plant iron absorption via improved root systems and activated iron acquisition mechanisms. Plant Physiol Biochem 2016;105:162-73

43. Ansari MW, Trivedi DK, Sahoo RK, Gill SS, Tuteja N. A critical review on fungi mediated plant responses with special emphasis to Piriformospora indica on improved production and protection of crops. Plant Physiol Biochem 2013;70:403-10.

44. Bisht S, Pandey P, Bhargava B, Sharma S, Kumar V, Sharma KD, et al. Bioremediation of polyaromatic hydrocarbons (PAHs) using rhizosphere technology. Braz J Microbiol 2015;46:7-21.

45. Sahoo RK, Bhardwaj D, Tuteja N. Biofertilizers: A sustainable ecofriendly agricultural approach to crop improvement. Plant Acclimation to Environmental Stress. New York: Springer Science Plus Business Media; 2013. p. 403-32.

46. Janaki T. Biocontrol of fusarium oxysporum in unsterilized soil by novel streptomyces cacaoi subsp cacaoi [M20]. Int J Pharm Pharm Sci 2017;9:3.

47. Steinkamp G, Wiedemann B, Rietschel E, Krahl A, Gielen J, Bärmeier $\mathrm{H}$, et al. Prospective evaluation of emerging bacteria in cystic fibrosis. J Cyst Fibros 2005; 4:41-8.

48. Parke JL, Gurian-Sherman D. Diversity of the Burkholderia cepacia complex and implications for risk assessment of biological control strains. Annu Rev Phytopathol 2001;39:225-58

49. Berg G, Eberl L, Hartmann A. The rhizosphere as a reservoir for opportunistic human pathogenic bacteria. Environ Microbiol 2005; 7:1673-85

50. Egamberdieva D, Wirth S, Alqarawi AA, Abd Allah EF. Salt tolerant methylobacterium mesophilicum showed viable colonization abilities in the plant rhizosphere. Saudi J Biol Sci 2015;22:585-90.

51. Tyler HL, Triplett EW. Plants as a habitat for beneficial and/or human pathogenic bacteria. Annu Rev Phytopathol 2008;46:53-73

52. Klerks MM, Franz E, van Gent-Pelzer M, Zijlstra C, van Bruggen AH. Differential interaction of salmonella enterica serovars with lettuce cultivars and plant-microbe factors influencing the colonization efficiency. ISME J 2007;1:620-31.

53. Kumar A, Munder A, Aravind R, Eapen SJ, Tümmler B, Raaijmakers JM, et al. Friend or foe: Genetic and functional characterization of plant Endophytic pseudomonas aeruginosa. Environ Microbiol 2013;15:764-79.

54. Aujoulat F, Marchandin H, Zorgniotti I, Masnou A, Jumas-Bilak E. Rhizobium pusense is the main human pathogen in the genus agrobacterium/rhizobium. Clin Microbiol Infect 2015;21:472.e1-5.

55. León-Sicairos N, Angulo-Zamudio UA, de la Garza M, VelázquezRomán J, Flores-Villaseñor HM, Canizalez-Román A, et al. Strategies of vibrio parahaemolyticus to acquire nutritional iron during host colonization. Front Microbiol 2015;6:702.

56. Koh EI, Henderson JP. Microbial copper-binding siderophores at the host-pathogen interface. J Biol Chem 2015;290:18967-74.

57. Blaser M, Bork P, Fraser C, Knight R, Wang J. The microbiome explored: Recent insights and future challenges. Nat Rev Microbiol 2013;11:213-7

58. Chen KC, Ravichandran A, Guerrero A, Deng P, Baird SM, Smith L, et al. The Burkholderia contaminans MS14 ocfC gene encodes a xylosyltransferase for production of the antifungal occidiofungin. Appl Environ Microbiol 2013;79:2899-905.

59. Kang MJ, Strap JL, Crawford DL. Isolation and characterization of potent antifungal strains of the Streptomyces violaceusniger clade active against Candida albicans. J Ind Microbiol Biotechnol 2010;37:35-41.

60. Indupalli MD, Muvva V, Munaganti RK. Streptomyces cellulosae vjds-1, a promising source for potential bioactive compounds. Int $\mathrm{J}$ Pharm Pharm Sci 2015;7:7

61. Compant S, Duffy B, Nowak J, Clément C, Barka EA. Use of plant growth-promoting bacteria for biocontrol of plant diseases: Principles, mechanisms of action, and future prospects. Appl Environ Microbiol 2005;71:4951-9.

62. Das P, Mukherjee S, Sen R. Substrate dependent production of extracellular biosurfactant by a marine bacterium. Bioresour Technol 2009; 100:1015-9.

63. Tyrrell J, Callaghan M. Iron acquisition in the cystic fibrosis lung and potential for novel therapeutic strategies. Microbiology 2016;162:191-205. 